THE BNL AGS - A CONTEXT FOR RAON FACTORIES

I.S. Iittenberg

Brookhaven National Laboratory

Upton, New York 11973

BNL- -33259

DE83 015052

May, 1983

AOTIOE

PORTIG.JS of THS GEPENT AAE BIIERIQLE.

It has been reproxiuced from the best available copy to permit the broadest. possible availability.

\title{
DISCLAIMER
}

\begin{abstract}
This report was prepared as an account of work sponsored by an agency of the United States Government. Neither the United States Government nor any agency thereof, nor any of their employees, makes any warranty, express or implied, or assumes any legal liability or responsibility for the accuracy, completeness, or usefulness of any information, apparatus, product, or process disclosed, or represents that its use would not infringe privately owned rights. Reference herein to any specific commercial product, process, or service by trade name, trademark, manufacturer, or otherwise does not necessarily constitute or imply its endorsement, recominendation, or favoring by the United States Government or any agency thereof. The views and opinions of authors expressed herein do not necessarily state or reflect those of the United States Government or any agency thereof.
\end{abstract}

The submitted manuscript has been authored under contract DE-AC02-76CH00016 with the U.S. Department of Energy. Accordingly, the U.S. Government retains a nonexclusive, royalty-free license to publish or reproduce the published form of this contribution, or allow others to do so, for U.S. Government purposes. 
THE BNL AGS - A CONTEXT FOR RAON FACTORIES

L.5. Littenberg

Brookhaven Nat lonal Laboratory
Upton, Hev York 11973

Pigure 1 whows the Brookhaven ate with the AGS-CBA couplex highlighted. In this photograph the AGs 1s dwerfed by CaA and

indeed during the part few years future plane for particle physics at BNL have been dominated by this enormous project. However, very recently interest in future physice use of the has ial undergone trong revival. Indeed, aince the beginning of thif year, two projects for augwenting the AGS have been proposed. . Such
projects could keep the AGS vlable as research achine for any years to come. In general such schemes will also 1aprove the perforance and

It should be kept in aind that in apite of the fact the AGS has been perhape the wort frultful wachine in the history of high energy phystes, ${ }^{3}$ ite full capacitiee the never beco exploited. Eveo without Improvemente it: uefulneas as a cource of new phyalcu can be expected to continue for several years. At present it routinely pp111 every 2.4 protons/pulse in either sous extracted (one 1-sec aeparated by 220 nsec every 1.5 seconds) mode. 1t 1 s norally run at $28 \mathrm{cep}$ although 1t: energy can be more or less continuously varied from 32 down to $1.5 \mathrm{GeV} / \mathrm{c}$. In slow extracted mode the bean 18 shared by as any as 8 experimente and 2 teat beawe (see Figure 2). Table l 116te the currently avallable beats. The capabdlity for ecceleration of polarized protone vil moon be added. Table 2 gives auns of the experiweats serviced over the lant few years. Table 3 gived a breakup by aubject of recent and proposed expericents. These experiments constitute quite rich and varied progran. I wil discuse ase of thes lnd lidually a little later

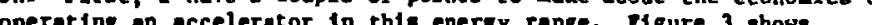
phyalcas output of the ACS (neasured ta experiant-weeks) verous operat ing cost in conetant dollers. Note, that in recent years. this has been in the region of $\$ 30 \mathrm{M}$. This is a meh higher figure than one of ten sees guoted as the operating cost of a kaon factory which after all ohould be more expenaive than the AGS to run. For \$10 $M$ one geta no physics at ali, and there 1s a break In the slope at about \$25 M. After this point one gete 1acrementally quite a bu core physics per dollar. Now although you and I think the sort of phyasce done at the AGS 1s exclting and laportant, soceone

intuential has reservations because the cost recent operating

budgets have allowed $<$ soz utilination of the eachine. Th1s 1s true in spite of the fact that we are operating on the steep part of the curve, where your dollor buy gre gose.

phyalcs one would build a kaon factory to pursue. The area in which

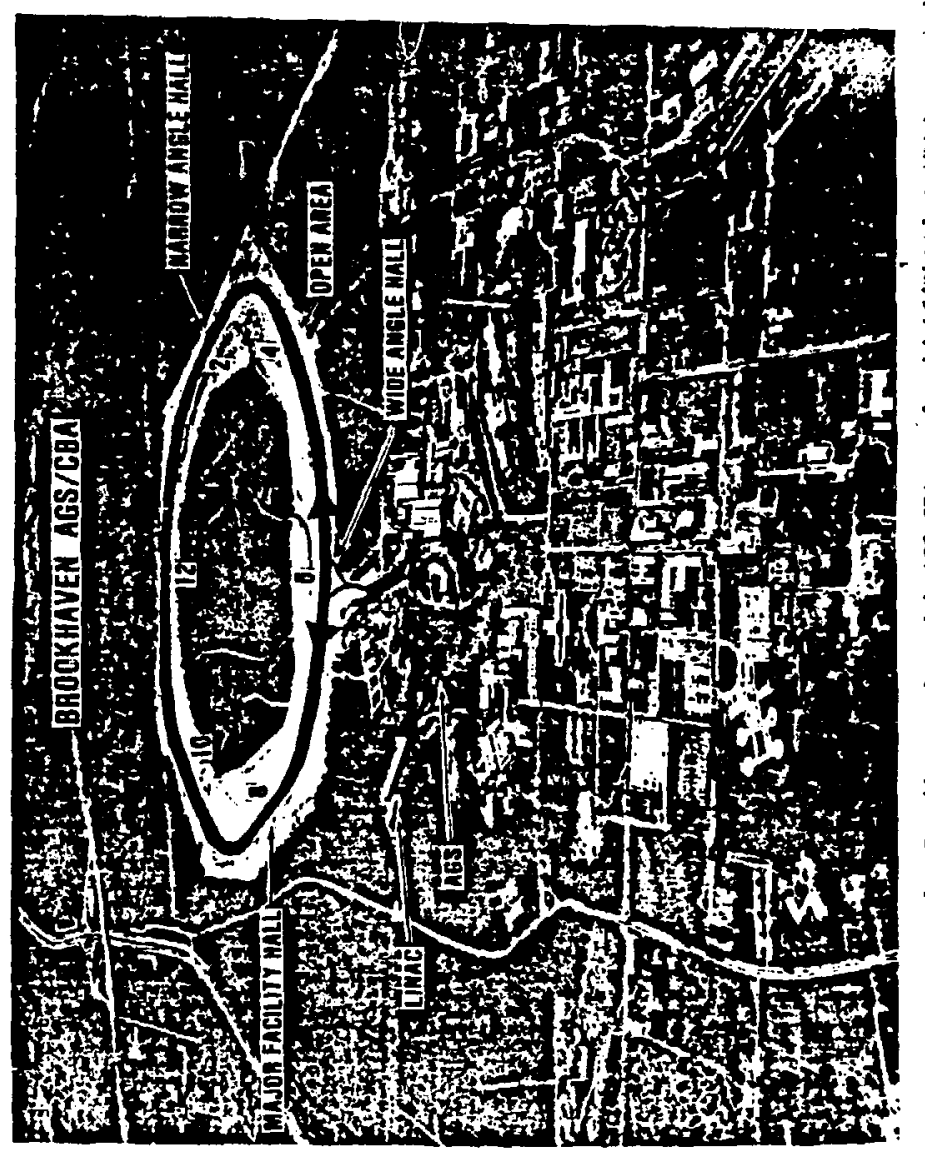

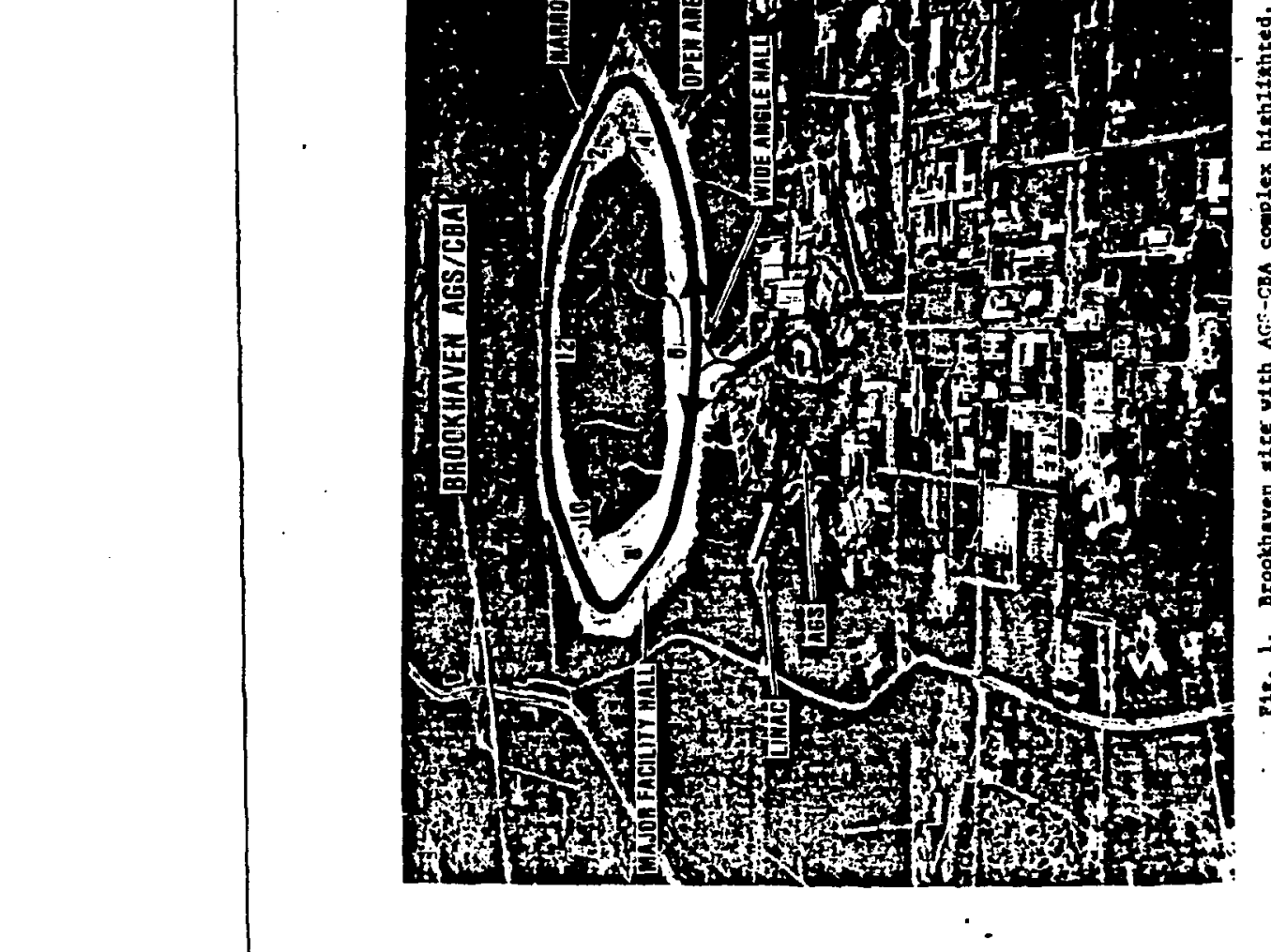



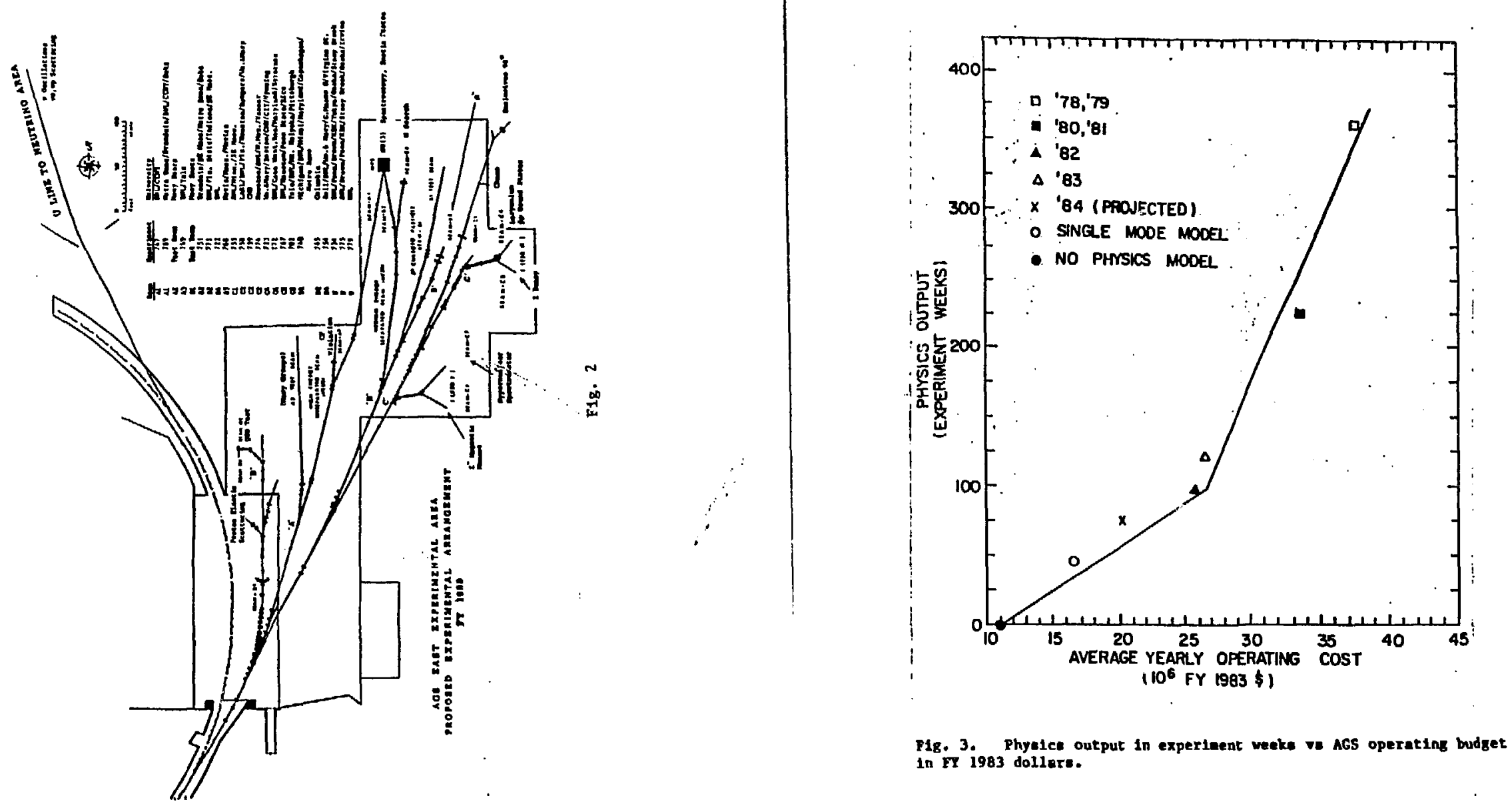


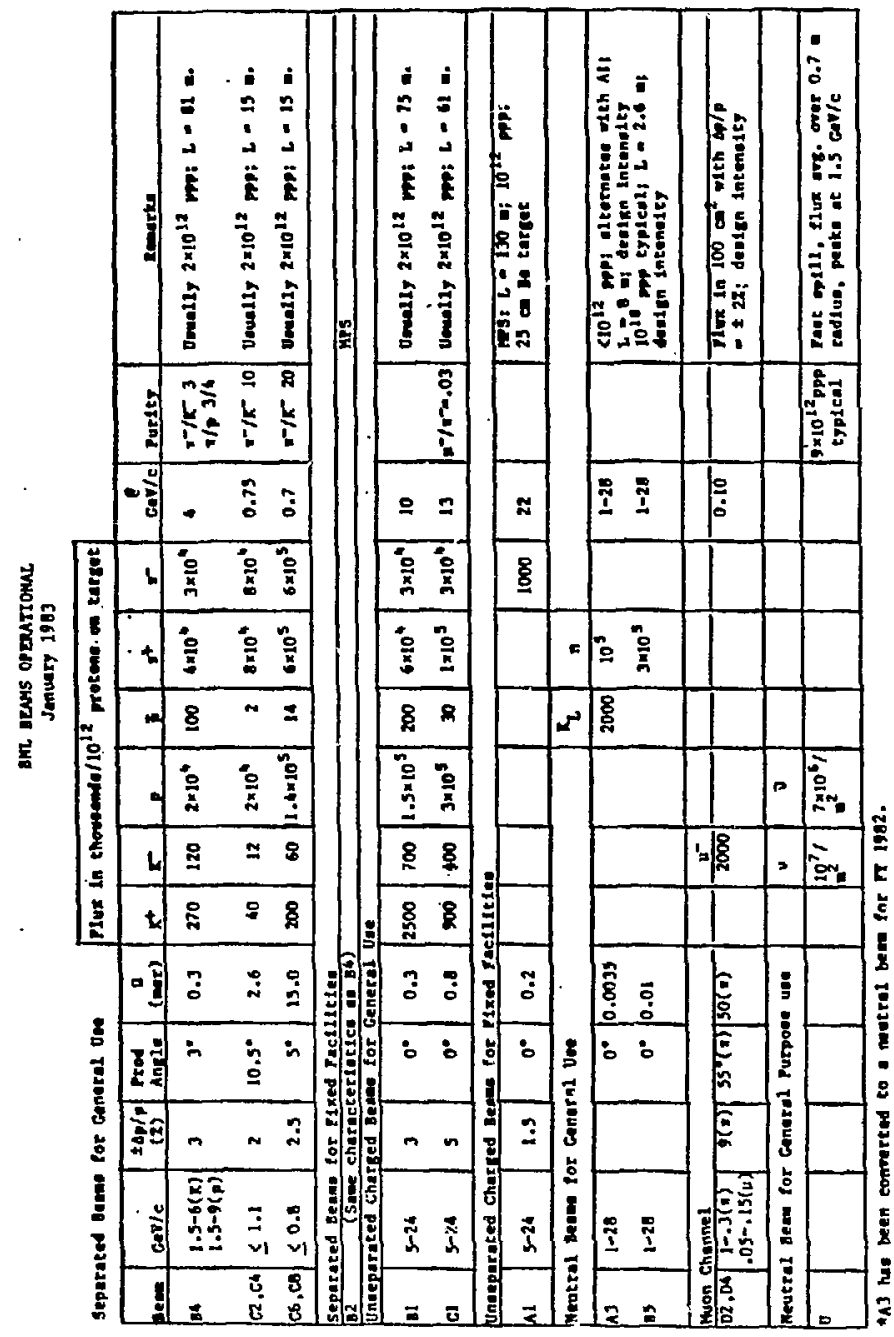

$\begin{array}{lrrrr} & \text { TABLE } 2 & & & \\ & \text { FY80 } & \text { FY81 } & \text { FY82 } & \text { TY83 } \\ & 359 & 314 & 278 & 270 \\ \text { AGS MANYEARS } & 26 & 24 & 23 & 21 \\ \text { AGS WEEKS } & 10 & 9 & 13 & 17 \\ \text { EXPERIMENTS SERVICED } & 181 & 142 & 168 & 251 \\ \text { NO. OF EXPERIMEHTERS } & 26 & 21 & 36 & 46 \\ \text { NO. OF INSTITUTIONS } & & & & \end{array}$

TABLE 3

\section{EXPERIKENTAL TOPICS}

GADRON SPECTROSCOPY

13

HADRON DTNAMICS

STMETRY TESTS

DETAILED ELECTRO-HEAT INTS

HTPERNUCLET

OTHER 
the full capability of the AGS 12 mout nearly exploited 1s that of $v$ phyalcs. The entire laternal bean is duaped on the v target and the

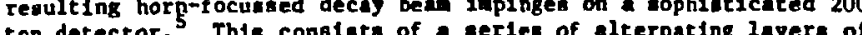

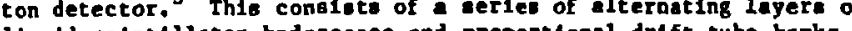
(aquid selntiln table 4)

$v_{\mu}+e^{-}+e^{-}+v_{\mu}$ and $\bar{v}_{\mu}+e^{-}+e^{-}+\bar{v}_{\mu}$ 1te desigaers took pains to keep the fraction of incetive waterinl in the detector to an abeolute aininua. In this way they hope to be able to distinguith electron howers from the far sorg coptows $\gamma$ thowers reaulting from processes like $v_{\mu}+{ }^{\prime} \wedge+v_{\mu}+z^{\prime}+x$. How well this worked 10 lliustrated dranticaliy by Figure 5 which gives the distribution of evente ldentifled as electroas yer.us those 'electron' events as expected for ve alastic acatters, whereas the 'photon' evente have no such atructure.

Next we move on to a palr of recently approved $x$ decay proposals. I wil be brief about these ance proponent of exch of theo are present at the conference and are avallable to diocuin then in detall. Both experiments segrch for posulble lepton flgvor

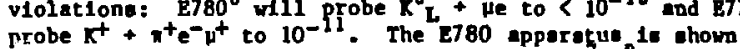
scheantically in Pigure 6 . A beas of $2 \times 10^{7} \mathrm{x}^{0}$ (and $6 \times 10^{\circ}$ neutrons) 1apinges on a drift chaber spectrometer. About 15 of the $x_{L}$ decay in the drift zone and about $10 \%$ of the two body decays are accepted by the spectrometer. In $1000 \mathrm{hr}$ experiment shi allow: then to get beyond $10^{-}$in statintical sensitivity. Of coure, to juatify thic, the background rejection alat be cormenourate. Electrons are 1dentified by a seguented hydrogen Cerenkov counter and a lead glase hodoscope. Muons ate distingulehed froe $x$ 's by meene of a hadron filter. In this experiment particle ldentificestion fo of linted vilue because the once auch a decoy has occurred the only recouree to to kipe chis,

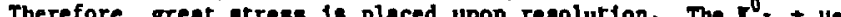

1s generally a 3-c fit ance one knowa the incoulng to

direction. in addition there is a vertex constraint ond consistency checks given by redundant chabers. Since one 1 s ahooting for a unique point in the paraneter apace given by the kinenatic, vertex, and other conatralnts, whereas the background to anoothly distributed in this opece, the better the resolution, the sanller the targ:at region and consequently the amilet the contanination. crudely one tends to gein $\propto$ a pover $a>2$ of the opatial resolution of the chambera. However, at a certain polnt, multiple coulonb scattering in the chambers anke further gaine in resolution almost 1mpossible. This point seens to be reached at contanination level

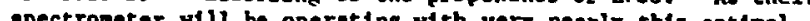

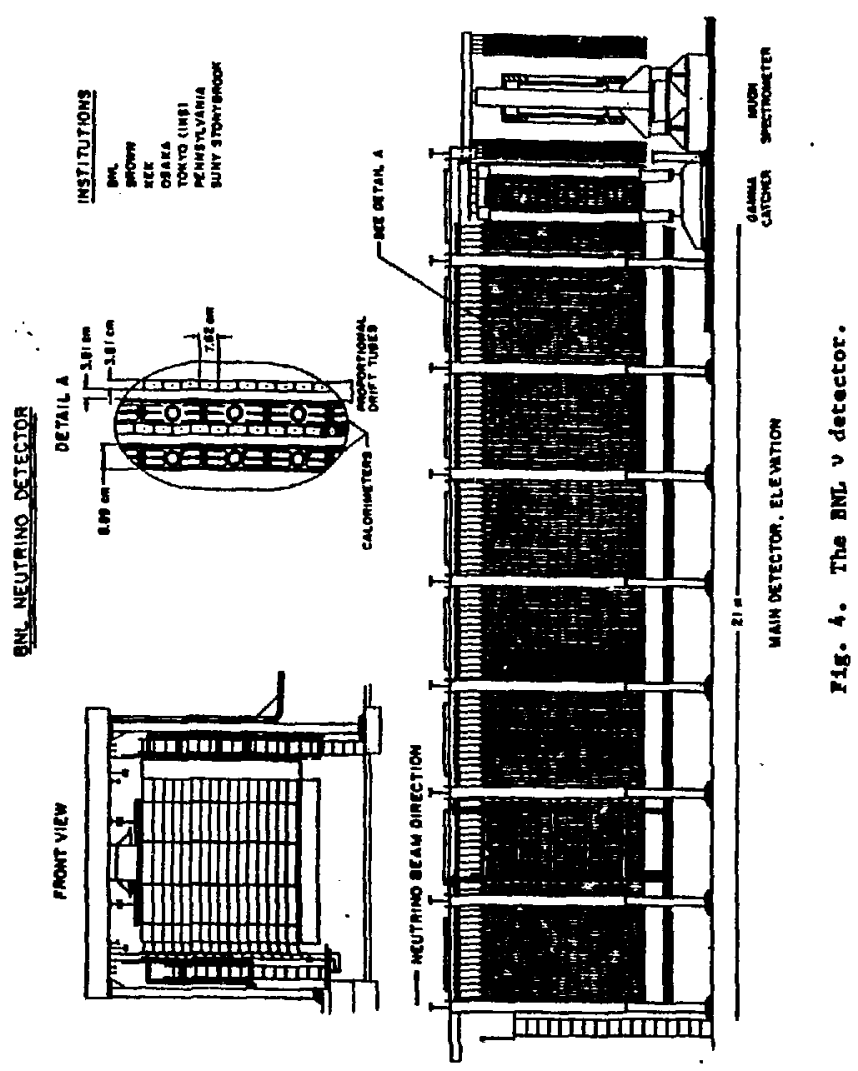




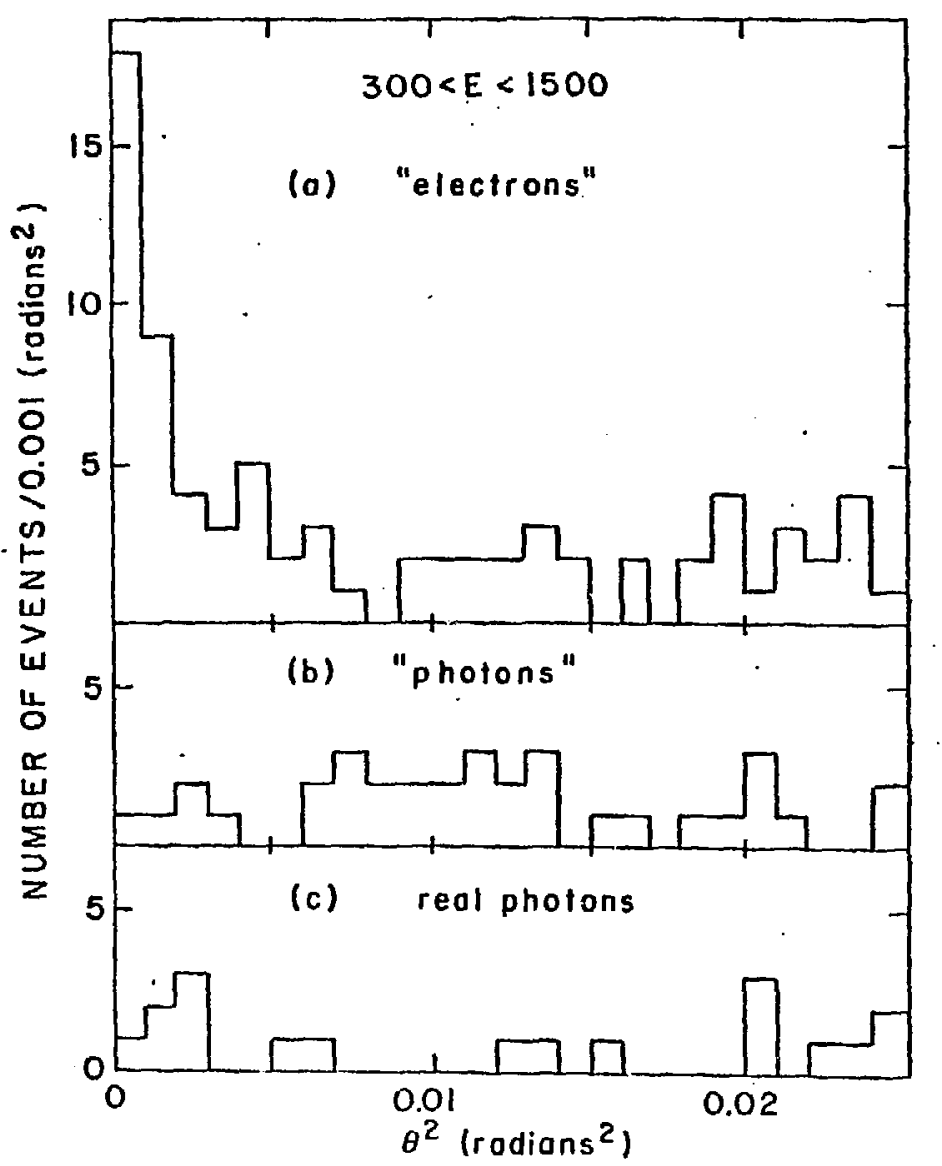

F1g. 5. Preliminary data from Experinent 734. D1stributione in the quas:ity for single shower eventa: a) Events in which the shower was identified as an electron, b) events in which the shower was
TABLE 4

BROORRAVEN KEUTRINO DETECTOR

LOCATION

INCIDENT BEAY

Brookhaven National Laboratory, Upton, NY 11973

Neutrino, Horn Focussed from $28 \mathrm{GeV}$ Protons 110* from protoo target

ASSEMBLI

Modular construction; each module consiating of plane of calorimeter and two planes $(x, y)$ of

tracking proportionsl drift tubes

112 Modules + y-Catcher + Spectroneter

Veight $172+30$ metric tons

MODURE PROPERTIES

CALORIMETER (LIQUTD SCINTILLATOR)

Active Area $4.22 \times 4.09 \mathrm{~g}^{2}$ Thickness $7.9 \mathrm{~cm}$

We1ght iLlquid 8 Acrg11d 1.35 metric tona

16 cells/module 2 Amperex $/ 2$ Time Measurements Per Tube Readout

PROZORTIONAL TODES (PDT)

Active Area $4.2 \times 4.2 \mathrm{~m}^{2} \quad 34 \times$ wires 54 y wires

Thulse Height. Hessurement/2 Time Messurements Per Wire Rendout

GAMMA CATCAER 10 atendard calorimeter modules with 1 sadiation length of lead between each module 30 metric tons target mass.

MUON SPECTROMETER

20 $\times 2$ - Aperture Huon Spectroneter

$\left\langle\int \mathrm{Bd}\right\rangle=70 \mathrm{MeV} / \mathrm{C}$

$(\Delta p / p)^{2}-\left(.10^{2}+(.067 p)^{2}\right) p$ in GeV/c 
resolution they expect to reach the $10^{-10}$ level falrly easily. The experiment 18 also sensitive to $\mathrm{K}_{\mathrm{L}}^{0}+\mathrm{H}^{+} \mathrm{H}^{-}$and $\mathrm{e}^{+} e^{-}$at about this

The E777 apparatus is shown in Figure 7. An unseparated 6 GeV/c beal is Incident on a PWC spectrometer. There are again about 20 niliton $x$, this the ano

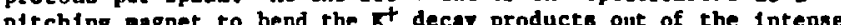
bean and to eeparate then by charge. On the negetive track alde electrons are identified and heavg particles rejected by two $\mathrm{H}_{2}$ Cerenkov counters and a lead glese hodoscope. On the positive side electrons w11l be refected by two $\mathrm{CO} 2$ or $\mathrm{N}_{2}$ Cerenkov counters and more lead glass, thereas nuons will be distinguithed from pions if a hadron filter. This heavy artillery 1s motivated by the fact that in this experiment, unlike $\mathrm{K}^{\text {o }}$ t He, large background suppression through particle ldentification is possible. However, once again the final recourse 18 to kineantics oo that good resoiation 18 also essential. About 102 of the $f^{4}$ decay sa the drift reglon, and the acceptance for $\mathrm{k}^{2}+\mathrm{x}^{+} \mathrm{e}^{-} \mathrm{u}^{+}+\mathrm{t}$ about $10 z$. This Fields an overall statistical senaltivity of 1 per $2 \times 10^{11}$ in $10^{6}$ pulsee. Resldual backgrounds are estinated to be at the few $\times 10^{-12}$ level, aking a sensitivity of $10^{-1}$ fenflble. The experinent may also be able to lok

$A$ third Interesting $K$ decay mode $19 \mathbf{K}^{+}+\boldsymbol{t}^{+} \mathrm{vv}$. Although no proposal has been sutticted, an expertaent sensitive to this sode st the $10^{-9}$ level 18 being planned. A possible detector 1s sketched in Figure 8. One would attempt to top about $10^{5} \mathrm{k} /$ pulae in a highly segmented 20 ca target. The full bean rate through thic target would then be roughly a macycle (malniy $x^{+}$). Charged decay product. are monentun analyzed in a cylindrical drift chamber systen nside a superconducting solenold. Range and energy of the

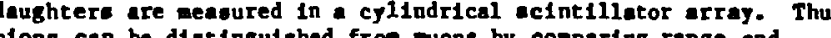

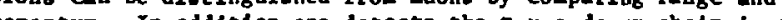
ectntillator array. The min backsrounds cone fron the domine

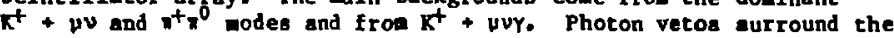
entire apparatus in an effort to muppress the latter two backgrounds. Since there 18 no unique kineatic signature for $k^{+}+x^{+} v_{\bar{v}}$, background rejection 1s absolutely cructal. Two body decay: wuch as $x^{+} x^{+}+$Familon as proposed by Hilcrek are quite geonetrtcal acceptance of - $50 z$, and accepts $50 \%$ of the momentus spectrum, the overail detection efficiency is only - 22 . This ts due to a numer of inds vidually eall or yoderate loses. (e.g.. pions interacting before ranging out. pulse helght and tialng cuts on decaying particles etc. $\%$. Thus for $10^{6}$ pulses at $10^{5} K^{6}$ stops/pulse one gets to the $10^{-9}$ level. One could also study

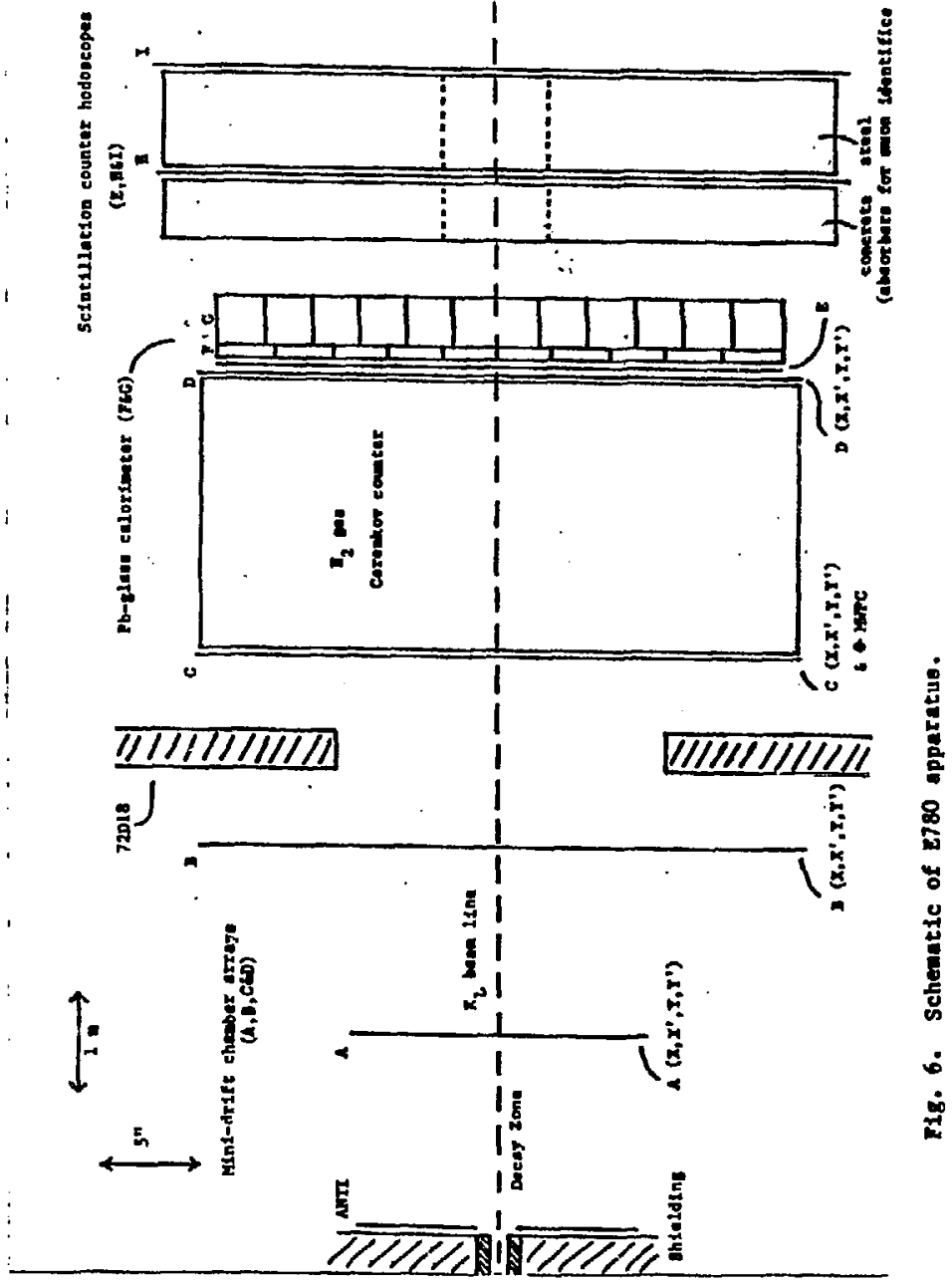




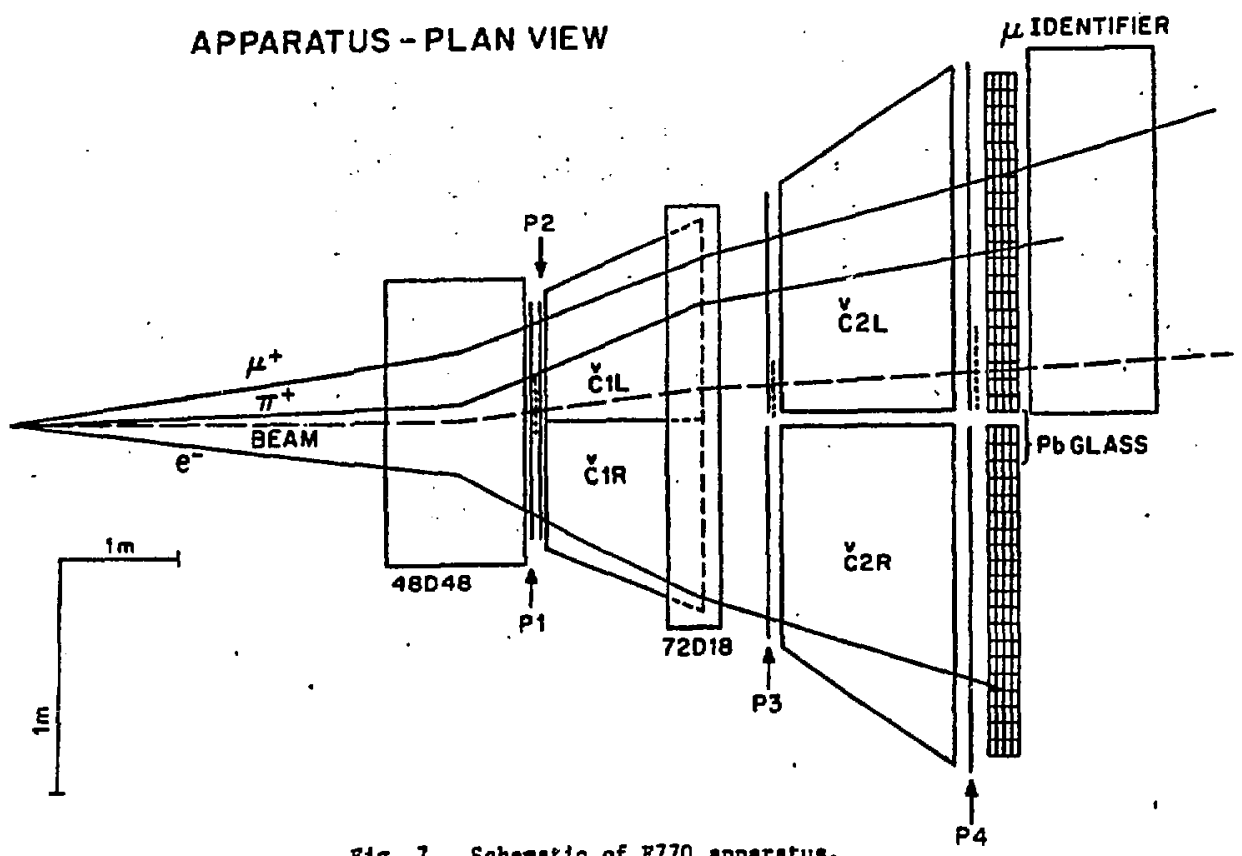

F1g. 7. Schearlic of 8770 apparatus.

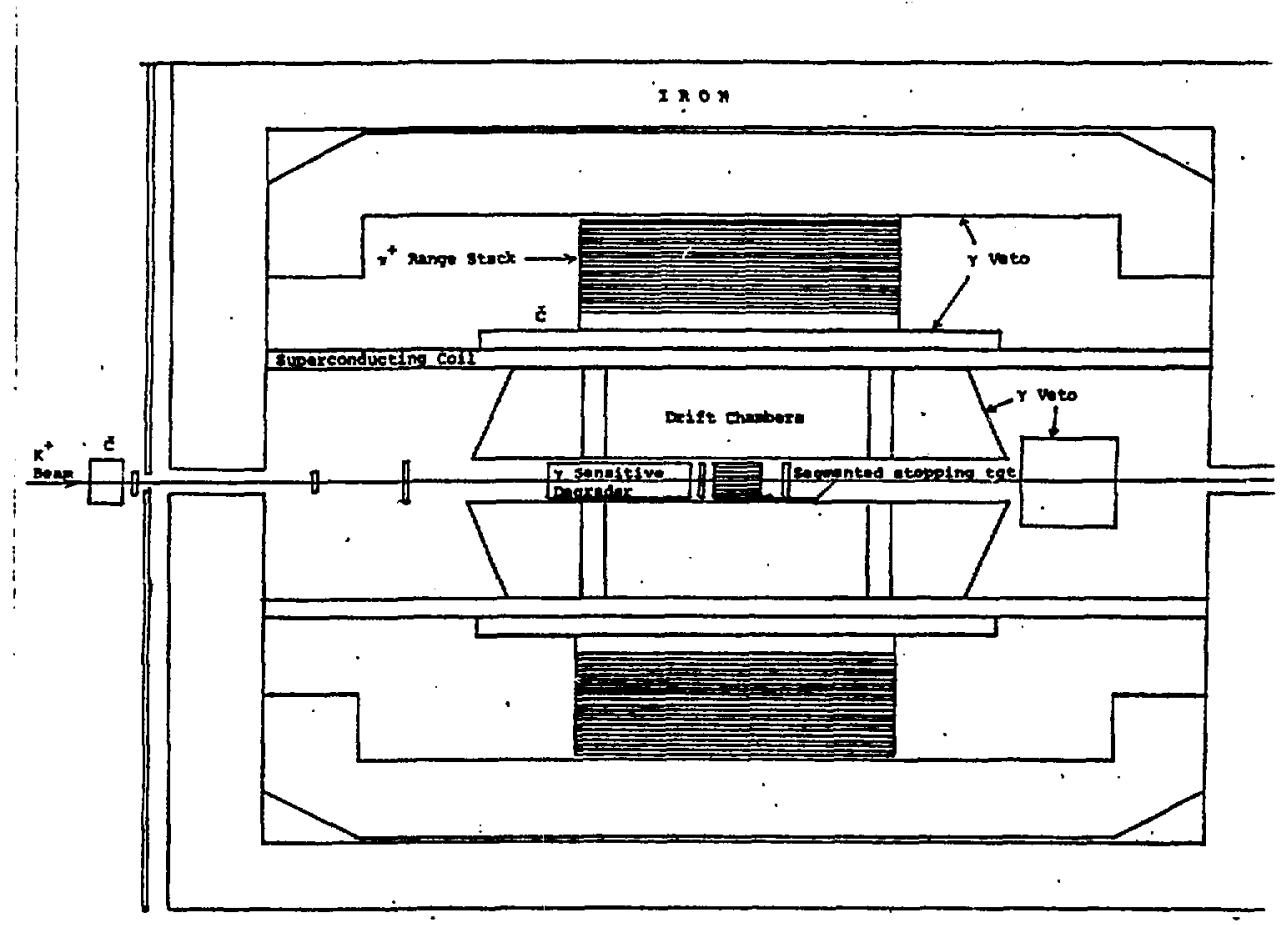

F18. 8. Poselble detector for $x^{+}+x^{+}$viv. 
Now I'd like to take up the subject of how far these cort of experiments wight be taken at the AGS. It weens hard to increase the number of $v_{\mu}$ events without Increasing the primary beal the slow bean program, one could run four or five tiaes longer than has been the case in recent years. One could also think about

aaking the detector lerger (or adding wore detectors). However, the present detector cost $\$ 6 \mathrm{M}$ and 1 t $\mathrm{b}$ bullders feel that $1 \mathrm{t}$ 1s already large enough to have reallzed nost of the poszible econonies of cale. Thus, to price a larger detector of comparable quality just wultiply $\$ 6 M$ by the ratio of tonnage. of courae, special purpose detectors of wore 1mited usefulness could cost less per ton (one has already beed approved for $v$ osclilatlos experiaent somewhat daunting to note thet the present bear-apparatun

conbination 18 not all that far from being rate linited (for $\nu_{\mu}$ ).

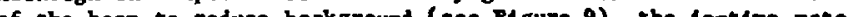
approe bes (triggerless) It tends to get confused by more than a few

events/spil1. Thus one can lasgine uning perhaps another order of angnitude but not auch aore in such an apparatus. Sy contrast,

and $\vec{v}_{e}$ interactions, or to be traded in for $v$ energy determination by making a narrow band beam.

As wentioned above 2780 is not expected to be background

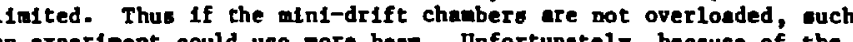

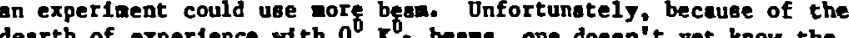
dearth of experience with 0 , ${ }_{1}$ beans, one doesn't yet know the ultionte $\mathrm{K}_{2}$ intensity and purity obtainable at the AGS. In fact.

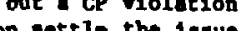

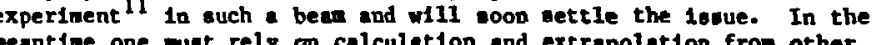
data. Th1s turns out to be rather difficult becaue date near 30 better but the extrapolation 1s. long one. Secondly, wost experisental results are off $\mathrm{H}_{2}$ and ao need to be corrected for $A$ dependence in order to predict the jield of a production target. There ere also corrections for multiple interactions, ben at tenuation etc., which art not entirely cut and dried. Two recent at tenpts 8 to calculate the flux dieagree by a factor 2 or 3 . If the wore optinistic estiante 1s right, the $n / \pi$ ratio in the bea Hll be around 30; If the ore pessinistic 1s correct, it w111 be pesela lake could get $6.5 \times 10^{5}$ usable $x^{0}$ ing the conservative nutbers, one have been delivered to targets at the aGS in the part, and alid angles up to -250 usr have been uoed. (E780 vili use $-10^{12}$ ) protons and $\Delta \Omega-15$ uBr). This would yield at least $6.5 \times 10^{8} \mathrm{~K}^{0} \mathrm{~L}$ pulse. For a decay tank of length $.03 \Lambda_{K}$ and an apperatus of

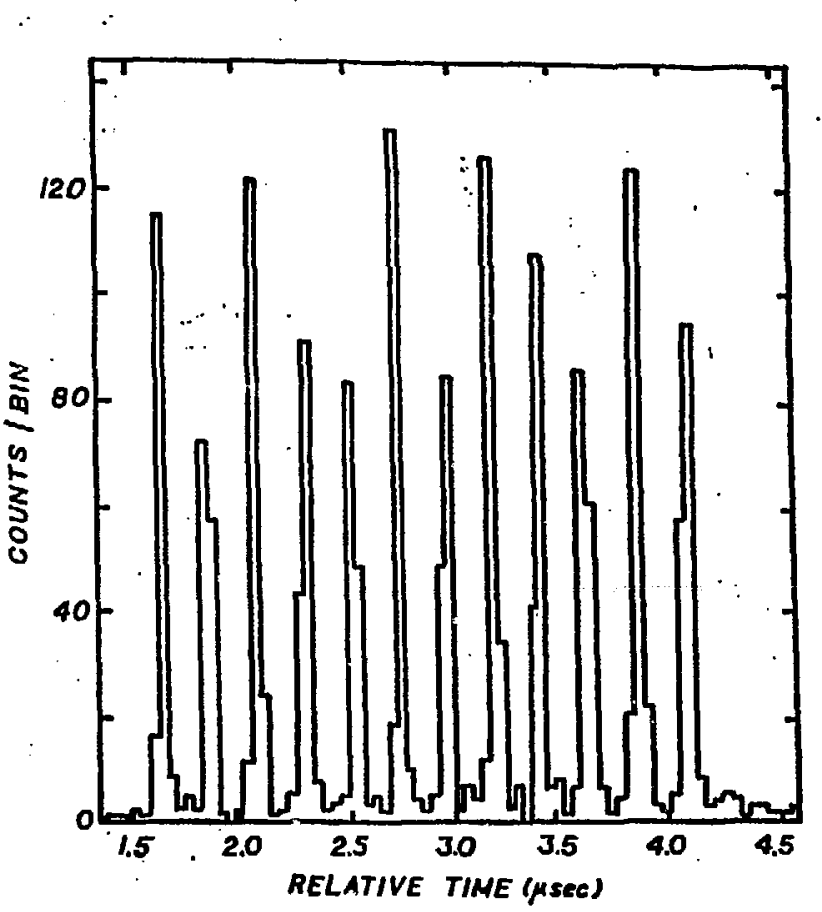

F1g. 9. Time distribution of $v$ event: from 8734 . 


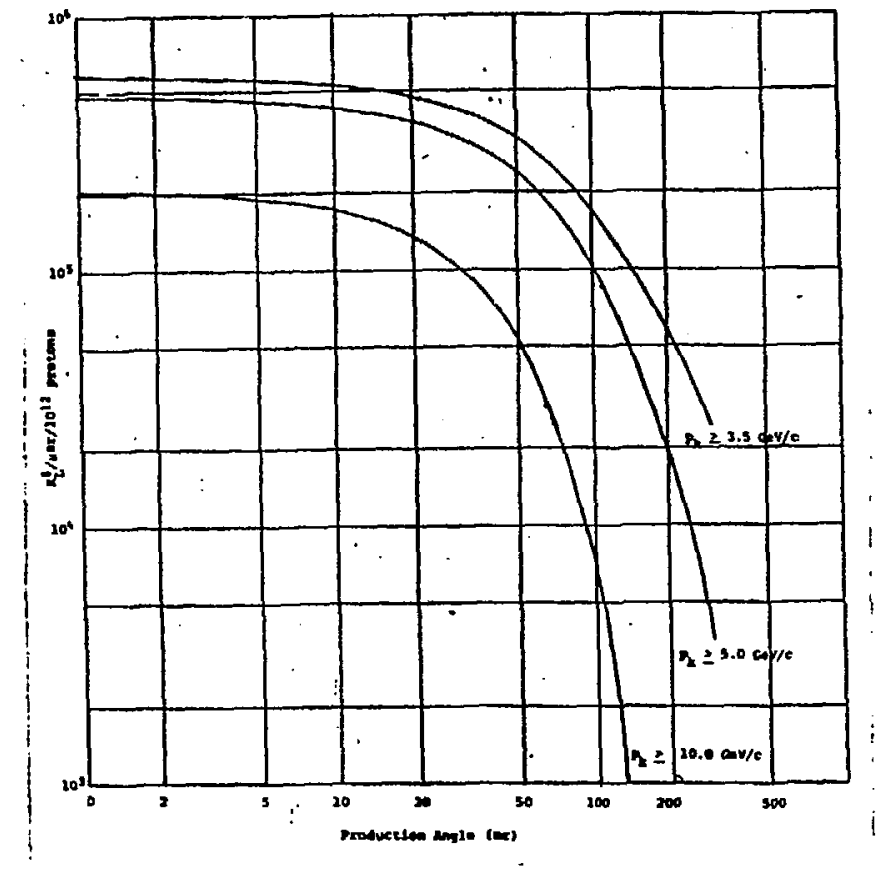

F1g. 10. $K^{0}{ }_{L}$ flux per $10^{12}$ protons on target per usr vs production angle for var1ous PK rangea (from Ref. 12). Assuaes
$28.5 \mathrm{GeV} / \mathrm{c}$ protons and one interaction length be target. acceptance $5 \pi$, one would reach a stat1ut1cal seasit1vify of $-10^{12}$ In $1000 \mathrm{hr}$ experineat The optiadst1c estimate of $K_{L}$ flux

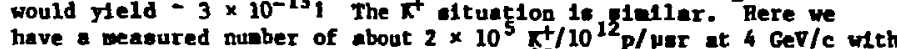

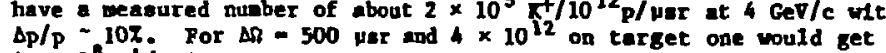
$4 \times 10^{8} \mathrm{~K}^{+}$/pulse accompanted by 20 times wre $\mathrm{p}^{\prime} \cdot$ and $\pi^{\prime} \%$. Then the

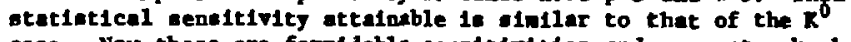
case. Now these are foridable sensitivities and we mat ask whet barrierw, other than raw $k$ fur, and in the way of achleving crit ine the cos 13 eneloper for

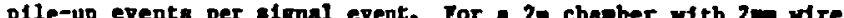

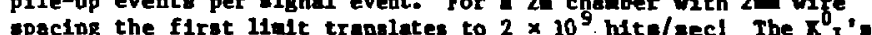
in the hot benis discused sbove ofll provide only $-3 \times 10^{7}$. Thus one 18 within the above 11 it if the hits due to $n$ interaction: are less than - 30 times thome Jue to $\mathbf{K}$ decays. Nor this wy sees quite safe, since the are assuning no more than $100 \mathrm{n} / \mathrm{K}$, and only a ansil fraction of these (certalnily not 1/3l) can be expected to cause chanber hits, but one ast be a little cautious. For one thing the high energy n 1nteractions will tend to be concentrated in the wires near the bean, for soother it is quite comanon in actual fact to have ten times the charber rates that one celculated in advance. As for plle-up, with a drift time of ay so naec, the average $R$ decay event will be accompanied by .6 eccidental event

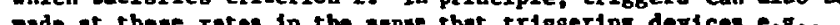
alti-elenent $c$ countere and electrontes ate faet enough, but the

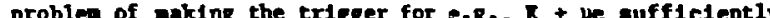
selective 1: nom-trivial. Boepts with an e and apperent if from kes decay will 1upinge on the detector at a rate of $>10 \% /$ sec. Kinematic qualities of the events will have to be exploited at rates 11ke these. This seens at least possible, if not eany. finaliy, we cone to linitatione due to Intrinale physics background. In the case of $\mathrm{K}_{2}+$ ve, according to the proponento of E780, one can 1oprove the background rejection by reducing the chamber recolution dow to about. 150, at which point MCS in the planes doelnates. At ehas prit one has about pae background event/10 sensitivity. Now this is not the linit of course. Hith enough atatistics one can see a siganl above quite a large background. However, to be generally accepted a history anking

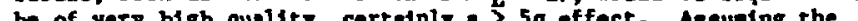
beve back then one could not clate a atgnel ach lese then - 28 events $\left(-8.5 \times 10^{-12}\right.$ ) 1.e., gbout the background 1evel. If one had

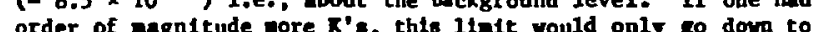
$2.7 \times 10^{-12}$. Th1s 11luatrates the general point that once a background is present, one tends to gain only as the aquare-root of the increase in statiotical sensitivity. 
The situation 15 similar for $\mathrm{K}^{+}+\mathrm{x}^{+} \mathrm{e}^{-} \mathrm{u}^{+}$. Assualng $10 \mathrm{z}$ of decaye occur within the fiducin region and a detection efficiency for these of $10 x$, in 1000 hours one could reach a statistical sensitivity level of $2.5 \times 10^{-}$. In E777 the proposed ensitivity is linited by a desire to keep the chamber rates from $\mathbf{k}^{+}+u^{+} \nu$ decaye below - few megacycles. Conpared with what we have discussed above this is very conservative indeed. In apite of the fact that the PWC resolution is nowhere near the state of the art, the expected residual background is at the fev $x$ lo the level. Thus it does not seen Impossible that the background conld ultiat sensitivity. Thin would allow one to pull out a convincing signal the $-10^{-12}$ lerel. I should inject note of realisa here ond point out that toth these ultinte experiments would be nassive undertakings involving techniques that are someuhat beyond the present state of the art. It would take several years of unrelenting effort to reach the target senaitivity levels, even if no anticipated sources of beckground or other 1mpediments were to show up. Elsewhere ${ }^{14}$ I have dincuased at length the sort of

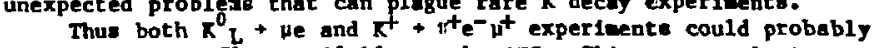
use the maxinua flux avallable at the Ais. This any not be true of $\mathrm{K}^{+}+\mathrm{x}^{+} \overline{\mathrm{v}}$ wh1ch $1 \mathrm{~s}$ more 11kely to be beckground 11mited. A recent test in the LESB $\mathrm{I}^{15}$ has show thet at $\mathrm{PK}^{+}=710 \mathrm{HeV} / \mathrm{c}$ one can stop well over $200,000 \mathrm{~K}+1 / 4 \times 10^{12}$ protong on target. This nuaber of protons/pulase has been routinely delivered to the $c$ target for some tiwe now. The $\pi / K$ rat 10 in the bens vas $-3-4$ to 1 and about
$40 z$ of the bean $\pi^{+}$were stopped in lucite target 10 in dianeter and $20 \mathrm{~cm}$ long. Ra1sing the bean mosentue to $750 \mathrm{MeV} / \mathrm{C}$ 1ncreased the yield of stopped $K^{+}$proton on target by a factor 1.7 without significantly degrading the tranuverse stopping dictribution. tine avallable for the test ran out before the $\mathrm{pX}^{+}=800 \mathrm{HeV} / \mathrm{c}$ setting could be optinized, but it was clear that another large Increment in atopping $\mathrm{K}^{+}$/proton on target could be reulized. A about this point one would probably atart comproulsing bead

properties (longer and wider stopping target necesany, more bean the could obta upwards of $500,000 \mathrm{~K}^{+}$per pulse under reasonable beal fonditions. under worae conditions. Since the present BM, beans are surely not the ultiaste one could deasgn it does not seen fantast could eventually stop - 14 r / pulee in good conditsons at the AGS.

Noy the question 1s whether one could begin to use such f flux In an experinent like $x^{+}+x^{+} \bar{v}$. Since at least one detector for this reaction with a 207 acceptance has been propoaed 17 at CERN, one can imagine statiatical sensitivities in the $10^{-11}$ ballpark. But decay $\mathrm{K}^{+}+\mathrm{p}^{+} \mathrm{vy}$ which occurs at about $3 \times 10^{-3}$ in the kinesatic region of interest. One would need to reject this by at least $10^{-9}$ to reach the renaitivity for $\bar{k}^{+}+n^{+} \bar{v}$ diccuesed above. One can probably get $>{ }^{0^{-3}}$ refection of $\mu^{\prime} \cdot$ by comparing energy an range.

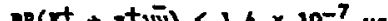
The expervation of the $x, 1+$ decay cha1n to reject $y^{\prime}$ ' by about $10^{3}$ to 1 . Bow well $t$ technique works depend entirely on the aecidentel rate it the rock 11ke 15 , whe that of 1 he stopping $K$ bean would be wore increase the detector granulgrity by fact or 50 . This alght well valuable in the previous experisent to veto any apparent decays which occurred within about 50 nesc of aubsequent beal track. since the particles $1 \mathrm{n}$ a $15 \mathrm{MPz}$ bea come every 70 naec or 00 , it seems Inposalble in the case belag considered here. Thus I'd guega one would be lucks to get a rejection factor of $10^{3}$ by valting for the $x-\mu$ decay only. One then neede aomething 11ke - $10^{3}$ rejection of photon to reach the necessary suppreanion of $\mathrm{K}^{+}+\mathrm{u}^{+} \mathrm{vy}$. Since at low energy the photon attenuation length in about trice the radiation length, about 14 radiation lengthe of veto detector are necessary to achieve this. Even then, any cracks, dead opaces or Inactive abaorber undernine this rejection. That' wore, at the bean rate under diacukaion, randon retoing 1s 11able to induce unecceptable deadtise onless the reto device 18 extresely fast. Other buckgrounds produce equally daunting probleas at theae rates. Thu

Now although 1 concluded that each of the $X$ decay experiment. contre abe conld be purbed at the chs to abe tending to doelnate the AGS progren. plus the other intereating physica of the energy range could the puraued imultaneously. To allevinte theae probleme one way rightly ask whether the AGS intenaity could be increaned.

Th1: bringe us to the subject of AGS future plans. An mentioned above a progran allowigg the acceleration of polarized protono 1s under way at the AGS. The initial intensity is anticipated to be around $10^{16}$ protons/pulse. Although th1 1 a adequate for moat polerized proton experiments, such an intenaity would, in general, be useleas to wopolarized bean experiments. In addition the most intereating uses of polorized protons in CBA require the fall lualnosity. Thus to avold progra: conflicts it would be desiraple eventusily to ralae the polarized proton intensity to $10^{13}$ protone/pulse. To eccomplish this one probably needs both o greatly 1aproved Ion source and an acculalator ring. A proposal ${ }^{2}$ to bulld auch a ring has recently appeared. T1gure 11 shows the layout of the ring wich would be situated between parametere of the sing are given in Table 5. Twenty 200 Mep LIMAC 


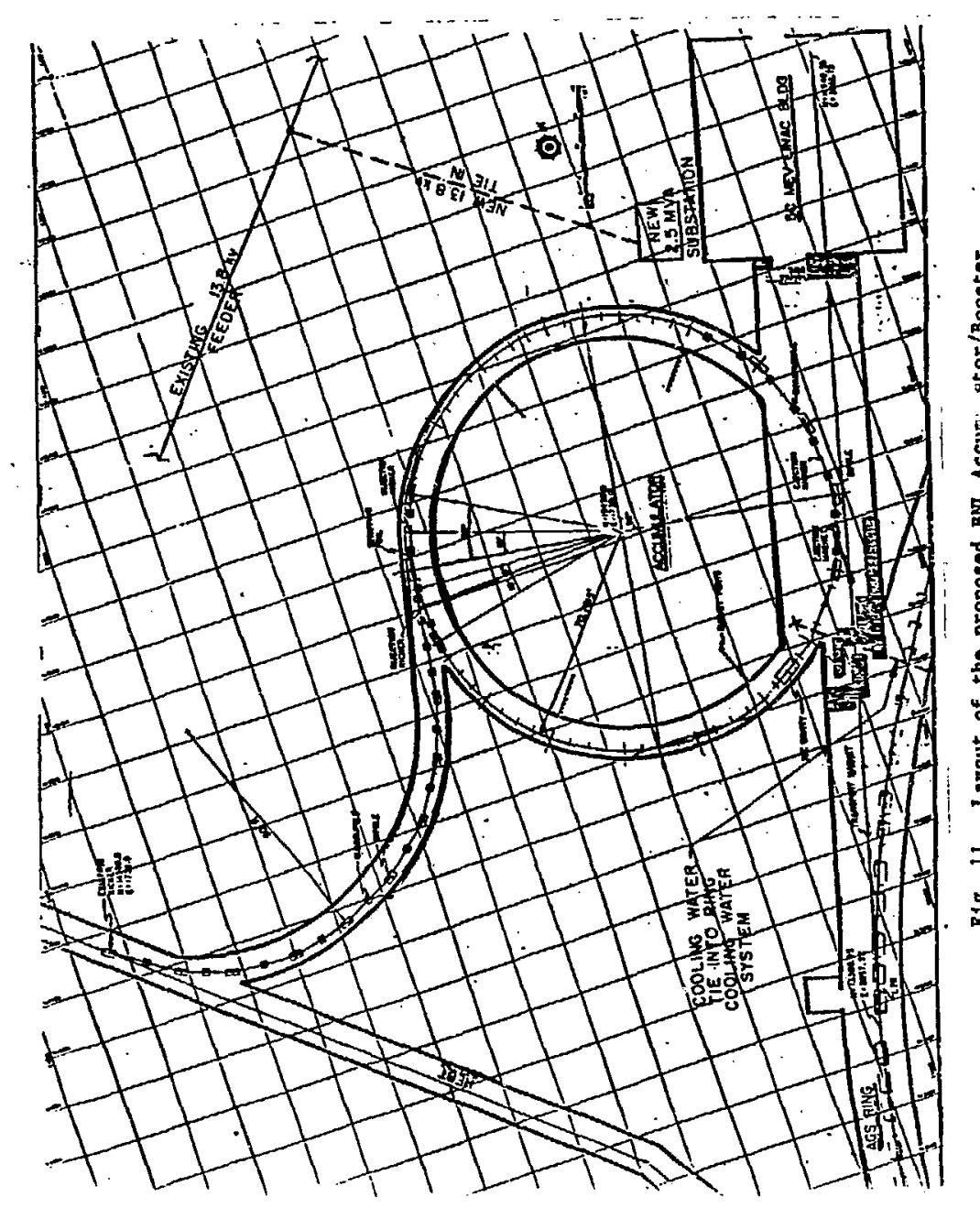

TABLE 5

Accunulator/Boostex Parametex B Energy

Injection Maxinum

Lattice

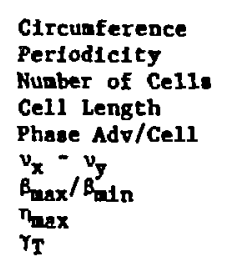

Nunber of Stations

Marnonic Number

Peak RF Voltag

Synchronous Phase Angle

Capture

Acceleration (future)

D1pole

Number

(1ron)

Gap

Good Field Region

Field (Inj/Max.)

Quadrupale

Number

Aperture
$200 \mathrm{MeV}$

$1000 \mathrm{MeV}$

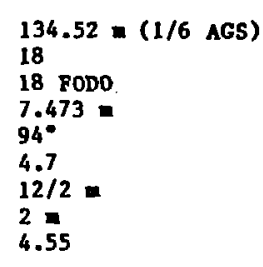

1
$18 \mathrm{kV}$

0 .

$30^{\circ}$

18

$75 " / 78.25 "(199 \mathrm{~cm})$

$3.25^{\circ}$

$3.73 \mathrm{~kg} / 9.82 \mathrm{kG}$

36

$20^{n}$
$8^{n \prime}$
$3.75 \mathrm{kG}$ 
TABLE 5 cont'd.

\section{Injection hine}

Number of D1poles (ongle)
Edge
Length (1ron)
Field
Number of Quadrupoles
Aperture
Length (Iron)
Field Gradient
Cuki

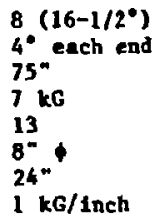

Vecuile

Max. Pressure

Chater Instade Dimensions
$10^{-9}$ Tors

$7^{2} \times 2.6^{*}$ (1n dipoles) pulses would be sccumulated in the ring (of ctrcunferance - 1/6 CAGS) and then Injected into the AGS V1a a ayachronous bucket to bucket transfer. Al only one of tep LINAC pulses/cee io currently uned by the AGS, the gein in intensity would be e fector 20 . This project which lncludes aco 16 dpoles and 36 quadrupoles 18 expected to cost ebout 86h. Mon of sore 1mediate interent to th1

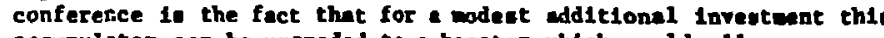
accunulator can be upgraded to a boostar which would allow cen-fold lincreane in the mpolerized Aas bean. This would, of course, drectly benelit che type of physce 1 have been diocunsing order to clrculvent the present apece cher the preoct opace cherge 1 in

the reaulting I GeV $10^{13}$-proton bunchea accunulated in the AGS. How of courwe, in order to accelerate, extract, and use such in intenae been there would need to be a muber of other inprovenente and edditions ande to the MCS beyond the addition of the accumulator ring. The cont important of thece are included in the following liat,

1. Add afgnficant accelerating copiollity to the $\mathrm{N} / \mathrm{BP}$

2. Hodify $\mathrm{W} / \mathrm{B}$ ring manet porer supplies to pernit $10 \mathrm{~Hz}$

3. Hodify the N/B extraction syaten sagnet and power usply

for $10 \mathrm{~Hz}$ operation.

4. Tranafer line fron $N / B$ and AGS injection eystem aut

5. Upgrade AGS vecuum from $10^{-7}$ to $10^{-6}$ Torr, wo that 1

6. New RF ayaten to accelerate $10^{14}$ protons/pulse. Totel $k$

7. Rediation harden rigg components, and add fest abort syoten.

8. Modification to besa lines and external ereas.

9. Add - etretcher ripg to ease extraction and ralue duty cycle to 1 .

The reault of theee efforta would be an AGS with 10 eines higher average intenaity then at present, with duty cycle of 1. A - alde benefit the NB would sllow the construction of $1 \mathrm{GeV} / \mathrm{c} \pi$ teat bein which could be avallable year round.

Inally I'11 discuas briefly the heavy ton proposal which

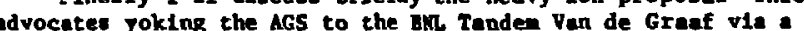
cjclotron (ace pigure 12). The cyclotron would be conatructed frow con:oonente of the SRM. cyclotron wich are already on the BNR

oite. Eventuelly the Tander $(.008$ A GeV) will feed the cyclotron (.15 A GeV) which in turn will feed the AGS ylelding up to 15 A GeV 


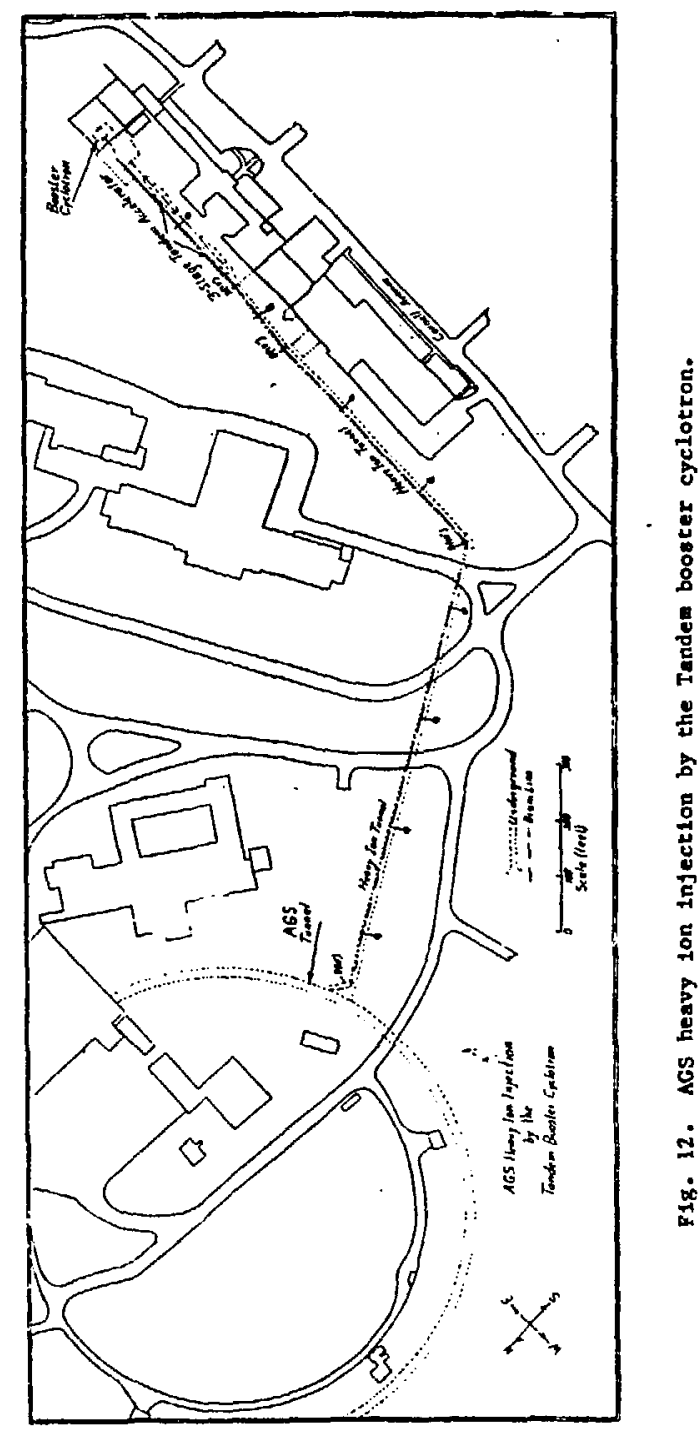

yielding currente of $10^{6}-10^{10}$ particles/pulee. Many combinations and pernutations are possdble. For example without the cyclotron one can lnject and accelerste loas up to $s$ ia the NGS. Table 6 thows araple AGs currente with and without the cyelotron. Whthout the AGs the cyclotron can feed partially etripped 1opa as heavy as

The project would take about four years and \$38H. The Tanden-AGS conbination could be ready in 2 years. The cost of one new that at the energJ deneity attalanble at this facility, the hypothesised QCD phase chenge uflll oceur, converting the collec whole

vitiantely the heavy lons could be injected into the CBA.

Figure 13 shows the energy ve ass range attainuble by varioue stagen of the project compured to that of the Bevelac.

In summary, it looke like quite a buey future for the AGS. Even without 1aprovenents at least one generation of rare $X$ decay experiment: beyond those currently launched meens fessible. Beyon that wajor effore at any of the experiwents discussed above could take it to the point where it would be linited by intrinaic phyuce background. To pursue full progran of physica at this level one would wanc to lvcreace the lnteasicy of the has as described above. $A$ cen-fold lncrease in $k$ Hux would remove such experinento ato category of all cout techologlcal assalte and texper thea cangeable by reation, could be pushed to linite unobtatoeble et the preent AGs. The increased flux would also be velcowed by the neutrino and

hypernuclear physice progran. Bven expericents thich do not at preaent require higher fluxes would benefit through the ovallability of purer beans and cleaner conditions.

The advent of polarized beams and of heavy ton acceleration will open up new whole areak of physics at the AGS. A 52 week progran will be hardly enough.

Thanke for discussions and ather help la preparing this talk go to J. Greenhelgh, R. Lanou, $D_{\text {. Lazarua, h. Louls, D. Lowenstein }}$
M. Marx, M. Murtagh, M.P. Schnidt, $L_{2}$ Snlth, and $Y$. Suzuk1.

This work is aupported in part by the U.S. Department of Energy

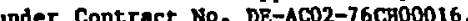




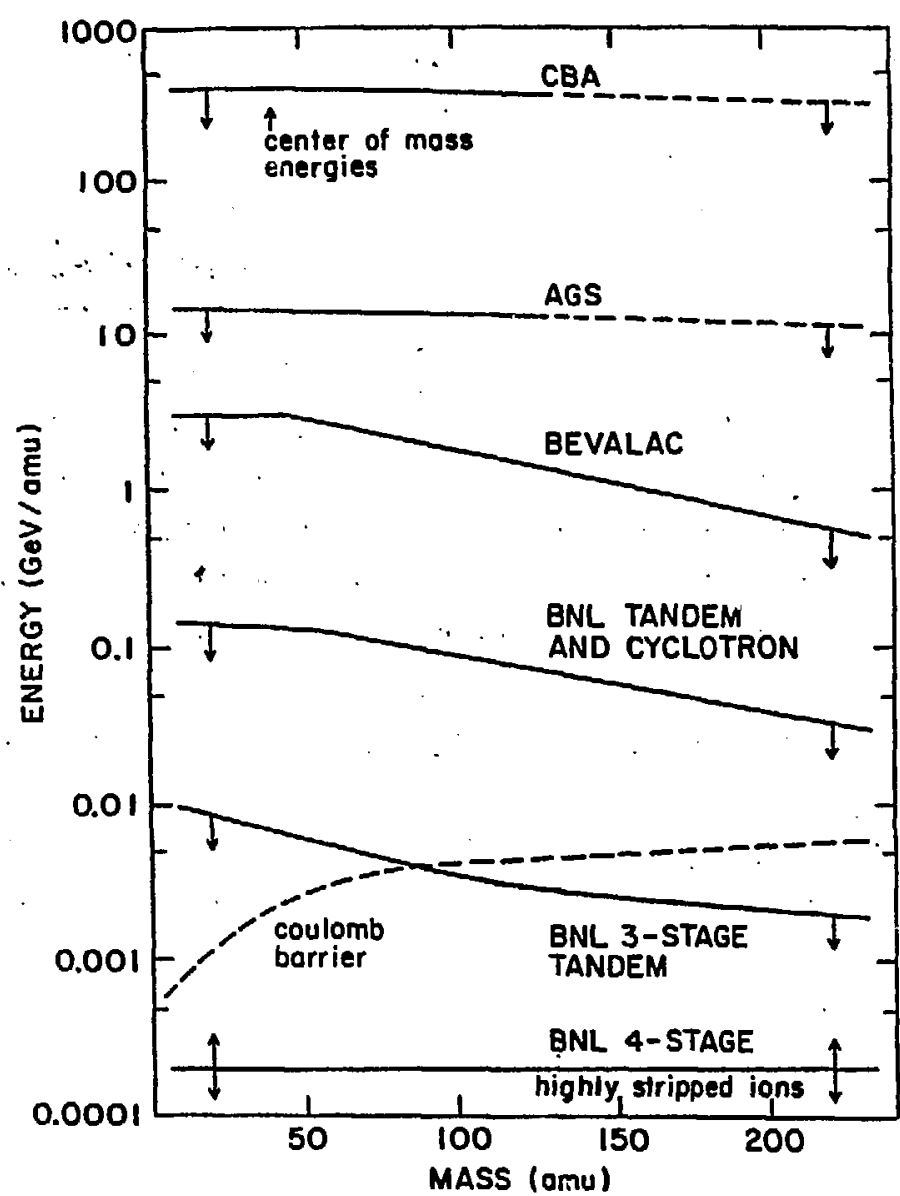

Pig. 13. Energy/nucleon vs ans for the BNL heavy ton accelerator conplex and
Indicated.

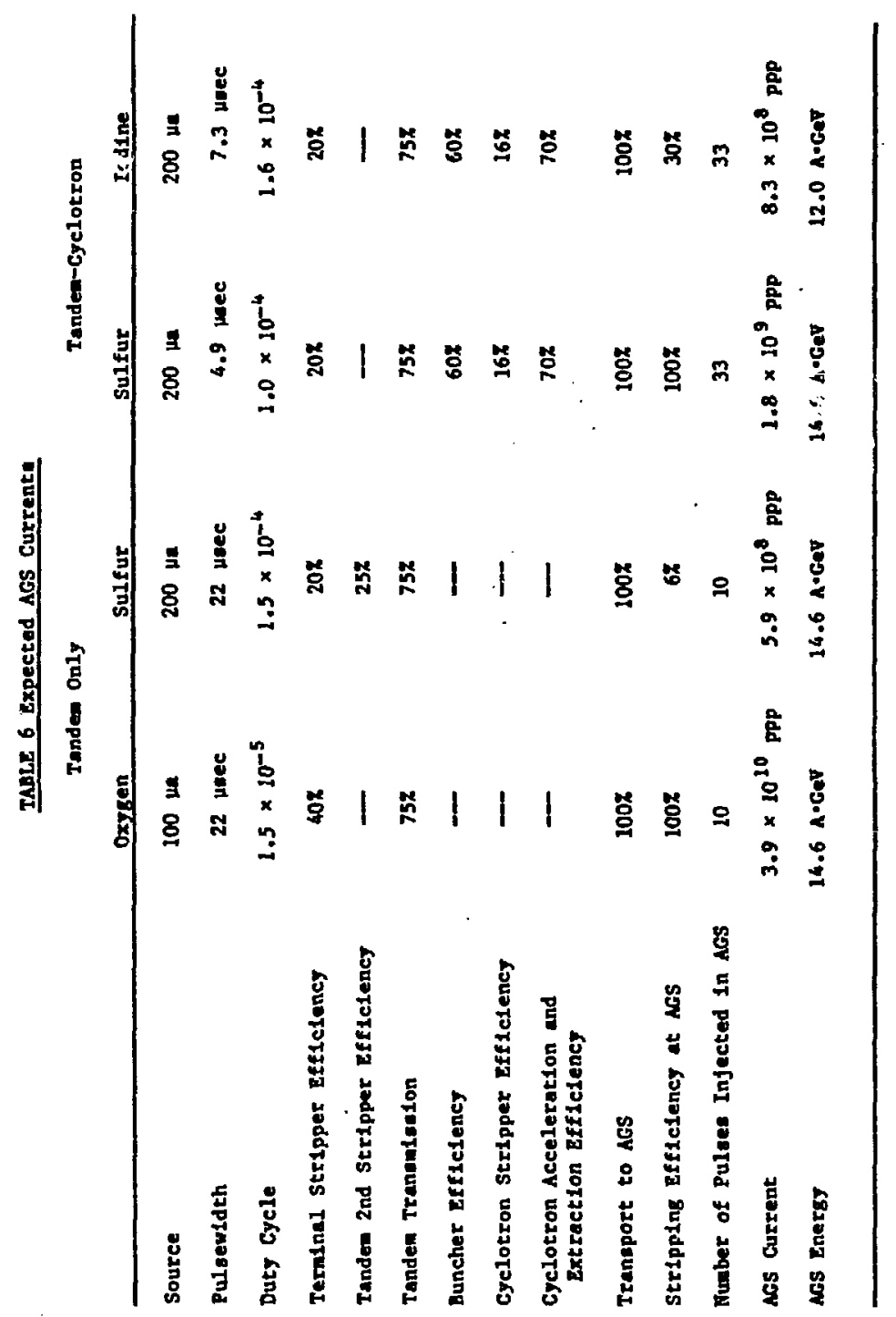




\section{REFERENCES}

1. "Proposal for a 15A GeV Heavy IOD Fac111ty at Brookhaven" BN 32250, Jenuary 1983.

2. "Proposal for an Accululator/Doonter for the AGS", March 1983, BNL 32949.

3. "Righ Energy Phyzice Achlevenents at the AGS and Conmotron", R.F. PhIll1p!, BN 1981. "AGS 20th Annivereary Celebration", H.V. Baggett, BNL 1980 .

4. K.M. Terwlli ger, et al., IEEE Trane. Huc. Scl., HS-28, Ho. 3 , June 1981 .

5. AGS Propaexl 734, BNL/Brown/Pennaylvania/ReR/Oraka/Stony Brook/Tokyo (INS)

6. R.C. Larsen, et el., AGS Propoeal $780,1982$.

7. D.M. Lazarus, et al, , AGS Proporel 7IT, 1981.

. F. vilczek, Phys. Rev. Lett. 49, 1549 (1982).

10. G. Dozok1, et s1., AGS Propoen1 776, 1981.

11. R.c. Larmen, et al., AGS Proposal 749, 1981.

12. J. Greenhalgh "On Eacianting the $\mathrm{K}_{2}^{0}$ Flux at $\mathrm{BNL}, 1982$

(unpublishad).

14. CBA Newaletter Ko. 5 , Lit Aprenberg "Rare $X$ Decayn", Proceedinge of the Second LAMPF II Workehop, Los Alenos, NM. July 1982, p. 728.

S. M.E. Zeller, et al., BNi Sumer Study on AGS Dt1l1zation 1970 p. 193.

16. D.M. Lazarus, BNL-21728, 1976.

17. M. Ferro-Luzz1, et al., CERH/PSCC 82-24 and 82-95 (1982).

18. Y. Aanno, et al., Phys. Lett. 1078, 159 (1981).

19. The tranalent digitisers uned in the experiment of Ref. 17 cost - $\$ 23,000$ a channell Although it'. probable that a cheaper olution can be found, one cannot multiply these entities

20. Alternatively the $A / B$, if built, could erve a the heavy ion 